\title{
Emerging Role of SGLT-2 Inhibitors for the Treatment of Obesity
}

\author{
Maria J. Pereira ${ }^{1}$ Jan W. Eriksson ${ }^{1}$
}

Published online: 30 January 2019

(c) The Author(s) 2019

\begin{abstract}
Sodium-glucose co-transporter 2 (SGLT2) inhibitors are glucose-lowering drugs that reduce plasma glucose levels by inhibiting glucose and sodium reabsorption in the kidneys, thus resulting in glucosuria. Their effects consequently include reductions in $\mathrm{HbAlc}$, blood glucose levels, and blood pressure, but also reductions in body weight and adiposity. The ability to reduce body weight is consistently observed in individuals taking SGLT2 inhibitors, but this weight loss is moderate due to counter-regulatory mechanisms striving to maintain body weight. This has prompted exploration of SGLT2 inhibitors in combination with other agents acting via decreased food intake, e.g., glucagon-like peptide 1 receptor agonists (GLP1-RAs). The bodyweight effects are promising, and together with the signs of prevention of cardiovascular and renal events, such combinations including SGLT2 inhibitors are appealing. The weight loss is clinically important, as most individuals with type 2 diabetes are overweight or obese, but also because there is an unmet need for safe, effective, and durable weight loss interventions in obese individuals without diabetes.
\end{abstract}

\section{Key Points}

With the increasing prevalence of obesity and associated co-morbidities, including impaired glucose tolerance and type 2 diabetes mellitus, novel treatment strategies are needed.

SGLT2 inhibitor monotherapy does not provide sufficient weight loss for successful treatment of obesity.

Co-administration of SGLT2 inhibitors together with agents that reduce food intake target complementary mechanisms and represent an effective weight loss therapy.

\section{Introduction}

Obesity is a growing health issue that has reached pandemic proportions, and in the last 15 years the estimated prevalence has doubled. In 2016, 1.9 billion (about 40\%) of the glo bal

Jan W. Eriksson

jan.eriksson@medsci.uu.se

1 Department of Medical Sciences, Clinical Diabetes and Metabolism, Uppsala University, 75185 Uppsala, Sweden adult population were overweight or obese, and of these 650 million were obese according to the World Health Organization [1]. Overweight and obesity, in particular, intra-abdominal adiposity, are associated with various cardiometabolic conditions including type 2 diabetes (T2D), dyslipidemia, hypertension, atherosclerotic cardiovascular disease, and heart failure [2, 3]. In addition, various musculoskeletal, respiratory, renal, gastrointestinal, and psychiatric complications are linked to obesity $[4,5]$. As a consequence, there are major implications for the affected individual's quality of life and also for society, including healthcare costs.

Weight loss in obese subjects improves several of the associated health issues, for example, prediabetes, diabetes, hypertension, and dyslipidemia [6-8]. Bariatric surgery has to date been the most effective treatment, and it has demonstrated a reduction of risks for cardiovascular events, cancer, and premature death, and pre-existing T2D is often reversed to normoglycemia [9-11].

The cornerstone treatment for overweight and obesity is lifestyle modification, mainly a lower energy intake in combination with increased physical activity. Adjuvant pharmacotherapies typically have demonstrated modest efficacy, and this may partly be due to physiological counter-regulatory mechanisms. Combination pharmacotherapies may achieve greater bodyweight loss than monotherapies, via additive or synergistic effects, when the individual agents target different pathways [12]. 
Selective sodium-glucose co-transporter 2 (SGLT2) inhibitors offer an insulin-independent mechanism for improving blood glucose levels and are approved for the treatment of T2D. They promote urinary glucose excretion by inhibiting glucose reabsorption from urine in the proximal tubule in the kidney (up to about 50\%). The magnitude of the resulting glucosuria is proportional to the plasma glucose above the threshold [13].

SGLT2 inhibitors (e.g., dapagliflozin, canagliflozin, and empagliflozin) and glucagon-like peptide-1 receptor agonists (GLP1-RAs; e.g., exenatide, liraglutide, and semaglutide) are both used for T2D treatment, but they also lead to bodyweight loss, largely accounted for by body fat reduction. Moreover, the glycemic as well as bodyweight effects are sustained over several years with these drug classes [14-16]. However, the magnitude of weight loss is modest both in T2D and in obesity without diabetes. For approved SGLT2 inhibitors there is on average some $1.5-2 \mathrm{~kg}$ weight loss (placebo-adjusted), for GLP1-RAs 2-4 kg, and for the combination 3-5 kg [17-23]. Thus, there is a need for more effective weight-loss therapies.

This article reviews current knowledge about weight loss with SGLT2 inhibitors in T2D subjects and obese subjects without T2D and provides future insight for using SGLT2 inhibitors alone or in combination therapy as treatment for obesity.

\section{Clinical Effect of SGLT2 Inhibitors}

The efficacy and safety of SGLT2 inhibitors have been extensively investigated, especially in combination with metformin and/or other glucose-lowering drugs in T2D patients. In addition to glucose control, SGLT2 inhibitors have been shown to have beneficial effects on body weight, systolic blood pressure, and on the risks for major cardiovascular and renal events. In this section, we provide an overview of the clinical effects of SGLT2 inhibitors in patients with T2D and in obese individuals without diabetes.

\section{Glycemic Control}

SGLT2 inhibitors have shown consistent reductions in $\mathrm{HbA1c}$ levels from baseline in patients with T2D at all time points. Meta-analyses show mean differences in $\mathrm{HbA} 1 \mathrm{c}$ reductions versus placebo of $-1.4 \%$ to $-0.5 \%[20,22$, 24-27]; these reductions are similar to those of other glucose-lowering agents [28]. These results are not surprising for a drug developed for the treatment of T2D. Clinical trials examining the effects of SGLT2 inhibitors in HbA1c in overweight or obese subjects without T2D are limited (Table 1). In two studies of 12- and 24-week duration,
SGLT2 inhibitors alone (canagliflozin and dapagliflozin, respectively) did not affect $\mathrm{HbA1c}$ levels compared to placebo in overweight and obese subjects [29, 30]. However, SGLT2 inhibitors in combination with a GLP1-RA significantly reduced $\mathrm{HbA1c}$ in obese subjects without diabetes, compared to placebo (Table 1) [30, 31].

Meta-analysis shows that SGLT2 inhibitors significantly reduce fasting blood glucose values from -2.0 to $-1.1 \mathrm{mmol} / \mathrm{L}$ [26]. The glucose-lowering capacity of SGLT2 inhibitors is blood glucose-dependent [32], which minimizes hypoglycemic events. The plasma glucose concentration is mainly determined by hormonal and neural factors (like insulin, glucagon, and catecholamines), which regulate endogenous production of glucose [33]. SGLT2 inhibitors stimulate hepatic glucose production and also increase glucagon secretion, which promotes endogenous glucose production and restricts their glucose-lowering capacity [34].

\section{Effects on Body Weight and Adiposity}

SGLT2 inhibitors directly cause body weight loss via glucose excretion (calorie loss) in the kidneys. Inhibition of SGLT2 acts in a glucose-dependent manner and can result in the elimination of about $60-100 \mathrm{~g}$ of glucose per day in the urine. Weight loss with SGLT2 inhibitor therapy has been consistently observed in several studies in T2D, whether patients are taking SGLT2 inhibitors as monotherapy or in combination with additional glucose-lowering therapies (Table 2). The results of network meta-analyses show reductions of body weight compared to placebo for all SGLT2 inhibitor treatments of about $1.5-2 \mathrm{~kg}[26-28,35]$ and these effects are dose-dependent [36]. Clinical data up to 4 years show that bodyweight reduction with SGLT2 inhibitors is maintained [37-39]. However, SGLT2 inhibitors cause substantially less weight loss than expected from the energy excreted via glycosuria, because it elicits an adaptive increase in energy intake, including compensatory increases in appetite/caloric intake [40]. Therefore, combining SGLT2 inhibitors with drugs acting via different mechanisms might be the most effective approach for major weight loss and address counter-regulatory mechanisms that maintain body weight [41]. Recent studies evaluating the co-administration of SGLT2 inhibitors with other classes of drugs have shown promising results. For example, the DURATION-8 study demonstrated that mean bodyweight loss with the combination of exenatide (GLP1-RA, which suppresses appetite) once weekly and dapagliflozin (SGLT2 inhibitor) once daily in patients with T2D was greater than that with the monotherapies alone [17].

Only a few studies have looked at the effects of SGLT2 inhibitors in weight loss in obese subjects without diabetes 
Table 1 Effects of SGLT2 inhibitors on body weight in obese individuals without type 2 diabetes

\begin{tabular}{|c|c|c|c|c|c|}
\hline Reference, year & $\begin{array}{l}\text { Dura- } \\
\text { tion } \\
\text { (week) }\end{array}$ & $N$ & Treatment arms & $\begin{array}{l}\text { Bodyweight } \\
\text { change from } \\
\text { baseline } \\
(\mathrm{kg})\end{array}$ & Other effects \\
\hline \multicolumn{6}{|l|}{ SGLT2 inhibitors } \\
\hline Bays et al. 2014 [29] & 12 & 376 & $\begin{array}{l}\text { Placebo } \\
\text { Canagliflozin } 50 \mathrm{mg} \\
\text { Canagliflozin } 100 \mathrm{mg} \\
\text { Canagliflozin } 300 \mathrm{mg}\end{array}$ & $\begin{array}{l}-1.1 \\
-1.9 \\
-2.8 \\
-2.4\end{array}$ & $\begin{array}{l}\downarrow \text { BMI, SBP } \\
\uparrow \text { UGE/creatinine ratio, LDL-C/ } \\
\text { HDL-C, IWQOL-Lite total scores } \\
=\text { TG, HDL-C, FPG, HbA1c, pulse } \\
\text { rate }\end{array}$ \\
\hline Napolitano et al. 2014 [82] & 8 & 30 & $\begin{array}{l}\text { Placebo + diet }(-500 \mathrm{cal}) \\
\text { Remogliflozin etaborate } \\
250 \mathrm{mg}+\operatorname{diet}(-500 \mathrm{cal}) \\
\text { Sergliflozin etaborate } \\
1,000 \mathrm{mg}+\operatorname{diet}(-500 \mathrm{cal})\end{array}$ & $\begin{array}{l}-5.1 \\
-7.6 \\
-6.1\end{array}$ & $\begin{array}{l}\downarrow \text { Fat mass, fat free mass, leptin/ } \\
\text { adiponectin } \\
\uparrow \text { UGE }\end{array}$ \\
\hline $\begin{array}{l}\text { Ramirez-Rodriguez et al. } 2018 \\
\text { [23] }\end{array}$ & 12 & 24 & $\begin{array}{l}\text { Placebo } \\
\text { Dapagliflozin } 10 \mathrm{mg}\end{array}$ & $\begin{array}{l}-1.0 \\
-3.0\end{array}$ & $\downarrow$ FPG, uric acid \\
\hline \multicolumn{6}{|l|}{ SGLT2 inhibitors +GLP1-RA } \\
\hline Lundkvist et al. 2016 [83] & 24 & 50 & $\begin{array}{l}\text { Placebo } \\
\text { Dapagliflozin } 10 \mathrm{mg}+\text { Exenatide } \\
2 \mathrm{mg}\end{array}$ & $\begin{array}{l}-0.4 \\
-4.5\end{array}$ & $\begin{array}{l}\downarrow \text { VAT, SAT, TAT, HbA1c, 2-h } \\
\text { PG, IFG, SBP } \\
\uparrow \text { UGE } \\
=\text { total lean tissue, liver fat, serum } \\
\quad \text { lipids }\end{array}$ \\
\hline Lundkvist et al. 2017 [21] & 52 & 50 & $\begin{array}{l}\text { Dapagliflozin } 10 \mathrm{mg}+\text { Exenatide } \\
2 \mathrm{mg}\end{array}$ & -5.7 & \\
\hline \multicolumn{6}{|l|}{ SGLT2 inhibitors + phentermine } \\
\hline Hollander et al. 2017 [42] & 26 & 335 & $\begin{array}{l}\text { Placebo } \\
\text { Canagliflozin } 300 \mathrm{mg} \\
\text { Phentermine } 15 \mathrm{mg} \\
\text { Canagliflozin + Phentermine } \\
\quad 15 \mathrm{mg}\end{array}$ & $\begin{array}{l}-0.6 \\
-1.9 \\
-4.1 \\
-7.3\end{array}$ & $\begin{array}{l}\downarrow \text { SBP } \\
\uparrow \text { Pulse rate (Phentermine, Canagli- } \\
\quad \text { flozin + Phentermine) } \\
=\text { plasma lipids }\end{array}$ \\
\hline
\end{tabular}

$B M I$ body mass index, $S B P$ systolic blood pressure, $U G E$ urinary glucose excretion, $L D L-C$ low density lipoprotein-cholesterol, $H D L-C$ highdensity lipoprotein-cholesterol, IWQOL Impact of Weight on Quality of Life, TG triglycerides, FPG fasting plasma glucose, VAT visceral adipose tissue, $S A T$ subcutaneous adipose tissue, TAT total adipose tissue, 2- $h$ PG 2-h post-OGTT plasma glucose, $I F G$ impaired fasting glucose, $\downarrow$ reduction, $\uparrow$ increase, $=$ no change

(Table 1). Bays et al. have shown that canagliflozin $100 \mathrm{mg}$ alone reduces body weight by $2.8 \mathrm{~kg}$ [29]. Co-administration of SGLT2 inhibitors with GLP1-RA reduces body weight by $4.5 \mathrm{~kg}$ at 24 weeks of treatment, and this weight loss is maintained for up to 1 year $(-5.7 \mathrm{~kg})$ in obese individuals without diabetes [21,30]. Most importantly, the weight loss is mainly due to a reduction in subcutaneous and visceral adipose tissue, rather than lean tissue. Another study exploring the combination therapy of canagliflozin with phentermine, an amphetamine-like medication used to suppress appetite and approved for weight management, demonstrated superior weight loss compared with placebo $(-7.3 \mathrm{~kg}$ vs. $-0.6 \mathrm{~kg})$ over a 26 -week period [42]. But studies exploring the effects of the combination therapy have been few and with limited doses. Therefore, the full potential for weight reduction needs to be explored in more studies including optimization of doses, safety, and inclusion of lifestyle intervention. There are currently other clinical trials evaluating the effects of SGLT2 inhibitors in obese individuals without diabetes used alone or in combination with other drugs (ClinicalTrial.gov identifier: NCT03093103, NCT03710460, NCT02635386, NCT02695810).

In diet-induced obese rats treated with SGLT2 inhibitors, lipolysis and circulating ketone body levels are increased $[43,44]$. In patients with T2D or with obesity without diabetes, SGLT2 inhibitor-induced glycosuria lowers plasma glucose and insulin levels and raises fasting and post-meal glucagon concentrations. The reduction in the circulatory glucose concentration, together with the hormonal changes, results in mobilization of lipid storage [24]. This leads to changes in energy substrate use, favoring the utilization of lipids for energy production [45]. Under conditions of reduced portal insulin-to-glucagon ratio, lipolysis increases in adipose tissue and releases non-esterified fatty acids which are converted to ketone bodies in the liver through mitochondrial beta oxidation and ketogenesis [25], resulting in a metabolic condition resembling a prolonged fast [26]. 
Table 2 Effects on body weight in randomized clinical studies using SGLT2 inhibitors as monotherapy or combined with other type 2 diabetes therapy

\begin{tabular}{|c|c|c|c|c|c|}
\hline Reference & $\begin{array}{l}\text { Duration to end } \\
\text { point (week) }\end{array}$ & $N$ & $\begin{array}{l}\text { Study } \\
\text { popula- } \\
\text { tion }\end{array}$ & Treatment arms & $\begin{array}{l}\text { Bodyweight change } \\
\text { from baseline }(\mathrm{kg})\end{array}$ \\
\hline \multicolumn{6}{|l|}{ SGLT2 inhibitor } \\
\hline Bailey et al. 2012 [84] & 24 & 282 & $\mathrm{~T} 2 \mathrm{D}$ & $\begin{array}{l}\text { Placebo } \\
\text { Dapagliflozin } 1 \mathrm{mg} \\
\text { Dapagliflozin } 2.5 \mathrm{mg} \\
\text { Dapagliflozin } 5 \mathrm{mg}\end{array}$ & $\begin{array}{l}-1.0 \\
-2.7^{\mathrm{a}} \\
-2.6^{\mathrm{a}} \\
-2.7^{\mathrm{a}}\end{array}$ \\
\hline Ferrannini et al. 2010 [85] & 24 & 485 & $\mathrm{~T} 2 \mathrm{D}$ & $\begin{array}{l}\text { Placebo } \\
\text { Dapagliflozin } 2.5 \mathrm{mg} \\
\text { Dapagliflozin } 5 \mathrm{mg} \\
\text { Dapagliflozin } 10 \mathrm{mg}\end{array}$ & $\begin{array}{l}-2.2 \\
-3.3 \\
-2.8 \\
-3.2\end{array}$ \\
\hline Ji et al. 2014 [86] & 24 & 326 & $\mathrm{~T} 2 \mathrm{D}$ & $\begin{array}{l}\text { Placebo } \\
\text { Dapagliflozin } 5 \mathrm{mg} \\
\text { Dapagliflozin } 10 \mathrm{mg}\end{array}$ & $\begin{array}{l}-0.3 \\
-1.6^{\mathrm{a}} \\
-2.6^{\mathrm{a}}\end{array}$ \\
\hline Kaku et al. 2014 [87] & 24 & 261 & $\mathrm{~T} 2 \mathrm{D}$ & $\begin{array}{l}\text { Placebo } \\
\text { Dapagliflozin } 5 \mathrm{mg} \\
\text { Dapagliflozin } 10 \mathrm{mg}\end{array}$ & $\begin{array}{l}-0.8 \\
-2.1^{\mathrm{a}} \\
-2.2^{\mathrm{a}}\end{array}$ \\
\hline Lambers Heerspink et al. 2013 [58] & 12 & 75 & $\mathrm{~T} 2 \mathrm{D}$ & $\begin{array}{l}\text { Placebo } \\
\text { Dapagliflozin } 10 \mathrm{mg}\end{array}$ & $\begin{array}{l}-0.1 \\
-2.4^{\mathrm{a}}\end{array}$ \\
\hline \multicolumn{6}{|c|}{ SGLT2 inhibitor + metformin or sulfonylurea } \\
\hline Bailey et al. 2010 [88] & 24 & 546 & $\mathrm{~T} 2 \mathrm{D}$ & $\begin{array}{l}\text { Placebo + Metformin } \\
\text { Dapagliflozin } 2.5 \mathrm{mg} \\
\text { Dapagliflozin } 5 \mathrm{mg} \\
\text { Dapagliflozin } 10 \mathrm{mg}\end{array}$ & $\begin{array}{l}-0.9 \\
-2.2^{\mathrm{a}} \\
-3.0^{\mathrm{a}} \\
-2.9^{\mathrm{a}}\end{array}$ \\
\hline Bailey et al. 2013 [89] & 102 & 546 & $\mathrm{~T} 2 \mathrm{D}$ & $\begin{array}{l}\text { Placebo + Metformin } \\
\text { Dapagliflozin } 2.5 \mathrm{mg} \\
\text { Dapagliflozin } 5 \mathrm{mg} \\
\text { Dapagliflozin } 10 \mathrm{mg}\end{array}$ & $\begin{array}{l}+1.4 \\
-1.1^{\mathrm{a}} \\
-1.7^{\mathrm{a}} \\
-1.7^{\mathrm{a}}\end{array}$ \\
\hline Bolinder et al. 2012 [90] & 24 & 182 & $\mathrm{~T} 2 \mathrm{D}$ & $\begin{array}{l}\text { Placebo + Metformin } \\
\text { Dapagliflozin } 10 \mathrm{mg}\end{array}$ & $\begin{array}{r}-0.9 \\
-3.0^{\mathrm{a}}\end{array}$ \\
\hline Bolinder et al. 2014 [37] & 102 & 182 & $\mathrm{~T} 2 \mathrm{D}$ & $\begin{array}{l}\text { Placebo + Metformin } \\
\text { Dapagliflozin } 10 \mathrm{mg}\end{array}$ & $\begin{array}{l}-2.1 \\
-4.5^{\mathrm{a}}\end{array}$ \\
\hline Strojek et al. 2011 [91] & 24 & 597 & $\mathrm{~T} 2 \mathrm{D}$ & $\begin{array}{l}\text { Placebo + Glimepiride } \\
\text { Dapagliflozin } 2.5 \mathrm{mg}+\text { Glimepiride } \\
\text { Dapagliflozin } 5 \mathrm{mg}+\text { Glimepiride } \\
\text { Dapagliflozin } 10 \mathrm{mg}+\text { Glimepiride }\end{array}$ & $\begin{array}{l}-0.7 \\
-1.2 \\
-1.6^{\mathrm{a}} \\
-2.3^{\mathrm{a}}\end{array}$ \\
\hline Strojek et al. 2015 [92] & 48 & 597 & $\mathrm{~T} 2 \mathrm{D}$ & $\begin{array}{l}\text { Placebo + Glimepiride } \\
\text { Dapagliflozin } 2.5 \mathrm{mg}+\text { Glimepiride } \\
\text { Dapagliflozin } 5 \mathrm{mg}+\text { Glimepiride } \\
\text { Dapagliflozin } 10 \mathrm{mg}+\text { Glimepiride }\end{array}$ & $\begin{array}{l}-0.8 \\
-1.4 \\
-1.5^{\mathrm{a}} \\
-2.4^{\mathrm{a}}\end{array}$ \\
\hline Bailey et al. 2015 [38] & 102 & 274 & $\mathrm{~T} 2 \mathrm{D}$ & $\begin{array}{l}\text { Placebo + Metformin } \\
\text { Dapagliflozin } 2.5 \mathrm{mg} \\
\text { Dapagliflozin } 5 \mathrm{mg} \\
\text { Dapagliflozin } 10 \mathrm{mg}\end{array}$ & $\begin{array}{l}-1.3 \\
-0.6 \\
-1.6 \\
-3.9^{\mathrm{a}}\end{array}$ \\
\hline Nauck et al. 2011 [93] & 52 & 814 & $\mathrm{~T} 2 \mathrm{D}$ & $\begin{array}{l}\text { Glipizide + Metformin } \\
\text { Dapagliflozin + Met }\end{array}$ & $\begin{array}{r}+1.4 \\
-3.2^{\mathrm{a}}\end{array}$ \\
\hline Nauck et al. 2014 [94] & 104 & 814 & $\mathrm{~T} 2 \mathrm{D}$ & $\begin{array}{l}\text { Glip + Metformin } \\
\text { Dapagliflozin + Metformin }\end{array}$ & $\begin{array}{l}+1.4 \\
-3.7^{\mathrm{a}}\end{array}$ \\
\hline Del Prato et al. 2015 [39] & 208 & 814 & $\mathrm{~T} 2 \mathrm{D}$ & $\begin{array}{l}\text { Glipizide + Metformin } \\
\text { Dapagliflozin (up to } 20 \mathrm{mg} \text { ) + Metformin }\end{array}$ & $\begin{array}{r}+0.7 \\
-4.4^{\mathrm{a}}\end{array}$ \\
\hline \multicolumn{6}{|l|}{ SGLT2 inhibitors + GLP1-RA } \\
\hline Fulcher et al. 2016 [95] & 18 & 95 & $\mathrm{~T} 2 \mathrm{D}$ & $\begin{array}{l}\text { Placebo + GLP1-RA } 300 \mathrm{mg} \\
\text { Canagliflozin } 100 \mathrm{mg} \text { + GLP1-RA } 300 \mathrm{mg} \\
\text { Canagliflozin } 300 \mathrm{mg} \text { + GLP1-RA } 300 \mathrm{mg}\end{array}$ & $\begin{array}{l}-0.6 \\
-3.3^{\mathrm{a}} \\
-3.9^{\mathrm{a}}\end{array}$ \\
\hline
\end{tabular}


Table 2 (continued)

\begin{tabular}{|c|c|c|c|c|c|}
\hline Reference & $\begin{array}{l}\text { Duration to end } \\
\text { point (week) }\end{array}$ & $N$ & $\begin{array}{l}\text { Study } \\
\text { popula- } \\
\text { tion }\end{array}$ & Treatment arms & $\begin{array}{l}\text { Bodyweight change } \\
\text { from baseline }(\mathrm{kg})\end{array}$ \\
\hline Frias et al. 2016 [17] & 28 & 695 & $\mathrm{~T} 2 \mathrm{D}$ & $\begin{array}{l}\text { Dapagliflozin } 10 \mathrm{mg} \\
\text { Exenatide } 2 \mathrm{mg} \\
\text { Dapagliflozin } 10 \mathrm{mg}+\text { Exenatide } 2 \mathrm{mg}\end{array}$ & $\begin{array}{l}-2.2 \\
-1.6 \\
-3.6^{\mathrm{a}}\end{array}$ \\
\hline Ludvik et al. 2018 [96] & 24 & 424 & $\mathrm{~T} 2 \mathrm{D}$ & $\begin{array}{l}\text { SGLT2 inhibitor + Placebo } \\
\text { SGLT2 inhibitor + Dulaglutide } 0.75 \mathrm{mg} \\
\text { SGLT2 inhibitor + Dulaglutide } 1.5 \mathrm{mg}\end{array}$ & $\begin{array}{l}-2.1 \\
-2.6 \\
-3.1^{\mathrm{a}}\end{array}$ \\
\hline \multicolumn{6}{|c|}{ SGLT2 inhibitor \pm DPP -4 inhibitor \pm metformin } \\
\hline Jabbour et al. 2014 [97] & 24 & 432 & $\mathrm{~T} 2 \mathrm{D}$ & $\begin{array}{l}\text { Sitagliptin } 100 \mathrm{mg}+\text { Placebo } \\
\text { Sitagliptin } 100 \mathrm{mg} \text { + Dapagliflozin } 10 \mathrm{mg}\end{array}$ & $\begin{array}{l}-0.1 \\
-1.9\end{array}$ \\
\hline Fulcher et al. 2016 [95] & 18 & 316 & $\mathrm{~T} 2 \mathrm{D}$ & $\begin{array}{l}\text { DPP-4 inhibitor + Placebo } \\
\text { DPP-4 inhibitor + Canagliflozin } 100 \mathrm{mg} \\
\text { DPP-4 inhibitor + Canagliflozin } 300 \mathrm{mg}\end{array}$ & $\begin{array}{l}-0.8 \\
-2.7^{\mathrm{a}} \\
-3.5^{\mathrm{a}}\end{array}$ \\
\hline DeFronzo et al. 2015 [98] & 52 & 674 & $\mathrm{~T} 2 \mathrm{D}$ & $\begin{array}{l}\text { Linagliptin } 5 \mathrm{mg} \\
\text { Empagliflozin } 25 \mathrm{mg} \text { + Linagliptin } 5 \mathrm{mg} \\
\text { Empagliflozin } 10 \mathrm{mg} \text { + Linagliptin } 5 \mathrm{mg} \\
\text { Empagliflozin } 25 \mathrm{mg} \\
\text { Empagliflozin } 10 \mathrm{mg}\end{array}$ & $\begin{array}{l}-0.3 \\
-3.1^{\mathrm{a}} \\
-2.7 \\
-2.8 \\
-2.9\end{array}$ \\
\hline Pratley et al. 2018 [99] & 52 & 1232 & $\mathrm{~T} 2 \mathrm{D}$ & $\begin{array}{l}\text { Sitagliptin } 100 \mathrm{mg} \\
\text { Ertugliflozin } 5 \mathrm{mg} \\
\text { Ertugliflozin } 15 \mathrm{mg} \\
\text { Sitagliptin } 100 \mathrm{mg}+\text { Ertugliflozin } 5 \mathrm{mg} \\
\text { Sitagliptin } 100 \mathrm{mg}+\text { Ertugliflozin } 15 \mathrm{mg}\end{array}$ & $\begin{array}{l}-0.1 \\
-2.4 \\
-3.2 \\
-2.4 \\
-2.8\end{array}$ \\
\hline Rosenstock et al. 2018 [100] & 24 & 534 & $\mathrm{~T} 2 \mathrm{D}$ & $\begin{array}{l}\text { Saxagliptin } 5 \mathrm{mg}+\text { Placebo } \\
\text { Dapagliflozin } 10 \mathrm{mg}+\text { Placebo } \\
\text { Saxagliptin } 5 \mathrm{mg}+\text { Dapagliflozin } 10 \mathrm{mg}\end{array}$ & $\begin{aligned} & 0.0 \\
- & 2.4 \\
- & 2.1\end{aligned}$ \\
\hline Mathieu et al. 2016 [101] & 52 & 294 & $\mathrm{~T} 2 \mathrm{D}$ & $\begin{array}{l}\text { Saxagliptin } 5 \mathrm{mg}+\text { Placebo } \\
\text { Saxagliptin } 5 \mathrm{mg} \text { + Dapagliflozin } 10 \mathrm{mg}\end{array}$ & $\begin{array}{l}-0.4 \\
-2.1\end{array}$ \\
\hline \multicolumn{6}{|c|}{ SGLT2 inhibitor + thiazolidinediones } \\
\hline Rosenstock et al. 2012 [102] & 48 & 420 & $\mathrm{~T} 2 \mathrm{D}$ & $\begin{array}{l}\text { Pioglitazone } \\
\text { Pioglitazone + Dapagliflozin } 5 \mathrm{mg} \\
\text { Pioglitazone + Dapagliflozin } 10 \mathrm{mg}\end{array}$ & $\begin{array}{l}+3.0 \\
+1.4 \\
+0.7\end{array}$ \\
\hline Kovacs et al. 2014 [103] & 24 & 498 & $\mathrm{~T} 2 \mathrm{D}$ & $\begin{array}{l}\text { Pioglitazone } \\
\text { Pioglitazone + Empagliflozin } 10 \mathrm{mg} \\
\text { Pioglitazone + Empagliflozin } 25 \mathrm{mg}\end{array}$ & $\begin{array}{l}+0.3 \\
-1.6^{\mathrm{a}} \\
-1.5^{\mathrm{a}}\end{array}$ \\
\hline \multicolumn{6}{|l|}{ SGLT2 inhibitor + insulin } \\
\hline Wilding et al. 2014 [104] & 104 & 808 & $\mathrm{~T} 2 \mathrm{D}$ & $\begin{array}{l}\text { Insulin } \\
\text { Insulin + Dapagliflozin } 2.5 \mathrm{mg} \\
\text { Insulin + Dapagliflozin } 5 \mathrm{mg} \\
\text { Insulin + Dapagliflozin } 10 \mathrm{mg}\end{array}$ & $\begin{array}{l}+1.8 \\
-1.0^{\mathrm{a}} \\
-1.0^{\mathrm{a}} \\
-1.5^{\mathrm{a}}\end{array}$ \\
\hline Rosenstock et al. 2014 [105] & 52 & 563 & $\mathrm{~T} 2 \mathrm{D}$ & $\begin{array}{l}\text { Insulin + Placebo } \\
\text { Insulin + Empagliflozin } 10 \mathrm{mg} \\
\text { Insulin + Empagliflozin } 25 \mathrm{mg} \\
\text { Insulin + Dapagliflozin } 10 \mathrm{mg}\end{array}$ & $\begin{array}{c}+0.4 \\
-2.0^{\mathrm{a}} \\
-2.0^{\mathrm{a}}\end{array}$ \\
\hline
\end{tabular}

$T 2 D$ type 2 diabetes; $S G L T 2$ sodium-glucose cotransporter 2; DPP-4 dipeptidyl peptidase 4; GLP1-RA glucagon-like peptide 1 receptor agonist ${ }^{\text {a }}$ Significantly different from placebo

Furthermore, SGLT2 inhibitors have been shown to reduce adipose tissue inflammation and to increase brown adipose tissue in rodent models [46, 47]. Reduction of inflammation in adipose tissue would be especially important in obesity, as low-grade chronic inflammation in adipose tissue is an important mediator in the development of obesity-related complications, such as insulin resistance and T2D [48]. 


\section{Cardiovascular Outcomes}

Cardiovascular outcomes trials with canagliflozin (Canagliflozin Cardiovascular Assessment Study; CANVAS), empagliflozin (Cardiovascular Outcome Event Trial in Type 2 Diabetes Mellitus Patients; EMPA-REG OUTCOME), and dapagliflozin (The Dapagliflozin Effect on Cardiovascular Events-Thrombolysis in Myocardial Infarction 58; DECLARE-TIMI 58) suggest that SGLT2 inhibitors reduce the risk of fatal and nonfatal cardiovascular events and the relative risk of hospitalization for heart failure [49-51], which might indicate a class effect. Overall, results were similar between these trials; however, cardiovascular death was not significantly reduced in CANVAS, and major adverse cardiovascular effects were not reduced in DECLARE-TIMI58. Differences in the study population or trial design could account for these differences.

The possible mechanisms by which SGLT2 inhibitors reduce cardiovascular risk are unknown, but are likely to include reductions in hyperglycemia and body weight, osmotic diuresis, and reduced blood pressure [52-54].

Obese individuals are at increased risk of cardiovascular disease when compared with their non-obese counterparts (men: 1.46 [1.20-1.77]; women: 1.64 [1.37-1.98]) [55]. Even though the effects of SGLT2 inhibitors on blood pressure and weight loss in obese individuals without T2D are identical to those reported in T2D subjects, it is unknown whether such effects can also translate into reduced cardiovascular disease events in this study population.

\section{Reduction in Blood Pressure and Arterial Stiffness}

High blood pressure is one of the most common co-morbidities associated with obesity [55]. Weight loss will reverse many of the pathophysiological mechanisms of obesity-related hypertension. Therefore, it makes sense to aim at a therapy that induces weight loss and reduces hypertension along with a path that could also improve glucose metabolism. Even though SGLT2 inhibitors are not approved as antihypertensive agents, most trials with SGLT2 inhibitors have reported reductions in systolic and diastolic blood pressure of about 3-7 and $2 \mathrm{mmHg}$, respectively $[24,56]$. Interestingly, the blood pressure reduction seems to be independent of disease status or presence of antihypertensive agents. The reason for the observed blood pressure reduction with SGLT2 inhibitors is not completely understood, but it is likely that several mechanisms including weight loss, diuretic effects, and reduction of the sympathetic activity are involved [57-59]. Furthermore, SGLT2 inhibitors have been shown to reduce arterial stiffness, thus also suggesting direct vascular effects. The significant decrease in blood pressure with SGLT2 inhibitors may provide a further advantage for obese patients when we take into account the high prevalence of hypertension among obese patients and the related cardiometabolic impact [60].

\section{Kidney Function}

Emerging data suggest that SGLT2 inhibitors reduce the risk of progression of renal disease in T2D subjects, with a similar benefit in those with and without renal impairment $[27,61]$ and with and without atherosclerotic cardiovascular disease [54]. Possible mechanisms of renal protection with SGLT2 inhibitors are multifactorial and it is likely that reduction in the glomerular capillary pressure, and reduction in an initial hyperfiltration, can contribute to the reduced albuminuria and prevention of renal impairment [62, 63]. However, these studies have limitations and were mainly conducted among populations with $\mathrm{T} 2 \mathrm{D}$ and predominantly normal to middle baseline kidney function. Other long-term trials designed to evaluate whether SGLT2 inhibitors have renal protective effects in participants with $\mathrm{T} 2 \mathrm{D}$, and without T2D but with or without chronic kidney disease and macroalbuminuria are ongoing (e.g., the "Evaluation of the Effects of Canagliflozin on Renal and Cardiovascular Outcomes in Participants With Diabetic Nephropathy (CREDENCE) study," NCT02065791; and the "EMPAagliflozin and RAs in Kidney Disease (EMPRA)," NCT03078101). In obese subjects without diabetes, SGLT2 inhibitors do not alter the estimated glomerular filtration rate or have any adverse event potentially related to renal impairment or renal failure over a 52-week period [21].

\section{Blood Lipids}

Generally, there are minor effects on lipid profile with SGLT2 inhibitor treatment. Even though some studies have shown that SGLT2 inhibitors modestly increase HDL cholesterol levels compared with placebo, there are also available data suggesting a small increase in LDL cholesterol $[26,29]$. Therefore, there is currently no clear evidence that changes in blood lipoproteins are of importance for the overall clinical outcomes following SGLT2 inhibitor treatment.

\section{SGLT2 Inhibitors in Type 1 Diabetes (T1D)}

SGLT2 inhibitors may also be of benefit in T1D, in addition to insulin, although they have not yet been approved for this indication. A few trials have assessed the efficacy and safety 
of SGLT2 inhibitors in T1D. SGLT2 inhibitors (dapagliflozin and empagliflozin) reduce $\mathrm{HbAlc}$ (about 2-4 mmol/L), body weight (1-2 kg), and the total required insulin dose compared to placebo $[64,65]$. In another trial, sotagliflozin, which can inhibit both SGLT2 and SGLT1, added to insulin significantly lowered $\mathrm{HbA1c}$, systolic blood pressure, and body weight, and required significantly less daily insulin compared to placebo [66]. One of the main concerns for any glucose-lowering drug in T1D is the risk of hypoglycemia. Notably, no increase in the hypoglycemic events is reported with SGLT2 inhibitors or sotagliflozin, compared to a placebo group in T1D subjects. However, a higher risk of diabetic ketoacidosis is observed with SGLT2 inhibitors. Therefore, more studies are needed with SGLT2 inhibitors in T1D patients, to fully evaluate their therapeutic potential in this specific population.

\section{Safety and Tolerability}

One advantage of SGLT2 inhibitors, compared with several other glucose-lowering therapies, is the low potential to induce hypoglycemia, unless combined with insulin or insulin secretagogues [25]. This is because urinary glucose excretion by default falls or ceases when plasma glucose drops, but there can also be contributions through sympathetic nervous activation during hypoglycemia that reduces the glomerular filtration rate and hence glucosuria [67], as well as through increased hepatic gluconeogenesis [68].

In general, SGLT2 inhibitors are well tolerated and the most common adverse effect is an increased risk of mycotic genital infections by about four- to sixfold versus placebo or active comparator, and this is seen in both women and men [26, 32]. This is a result of increased glucose concentration in the urine that can facilitate the onset of infections in the lower urogenital regions. The same mechanism is also expected to promote infections of the urinary tract, but in meta-analyses there is a trend for a minor increase up to 1.5-fold, and this is not consistent among studies [25-27]. The risks for such side effects are similar among different SGLT2 inhibitors.

Recent evidence suggests that episodes of ketoacidosis can also occur [69], and it might be of particular concern among insulin-deficient individuals, including those with longstanding T2D, T1D, or latent autoimmune diabetes in adults (LADA) [70].

Finally, the CANVAS program has reported an increased risk of bone fractures and lower-limb amputations with canagliflozin [49]. Neither bone fracture nor lower-limb amputation has been reported with the other SGLT2 inhibitors, or in another real-world analysis study [71], so additional evaluation is needed before drawing definite conclusions.

\section{Future Perspectives}

\subsection{Monotherapy}

Given the modest weight loss delivered by SGLT2 inhibitors, it is not likely that they will be successful as monotherapies for obesity. It could be argued that doses higher than those used to treat hyperglycemia may be more effective. However, as the glucosuric effect is self-limiting when plasma glucose is lowered, it is not expected to markedly increase efficacy. Accordingly, weight loss is not clearly improved in studies with a high degree of SGLT2 inhibition (like canagliflozin $300 \mathrm{mg}$ ) compared to partial inhibition, for example with empagliflozin $10 \mathrm{mg}$. The expected weight loss due to loss of up to $400 \mathrm{kcal}$ energy into the urine may be as much as $11 \mathrm{~kg}$ [40], but a compensatory increase of food intake probably accounts for the partial off-set of weight loss. Nonetheless, certain obese individuals at very high risk of T2D, atherosclerotic cardiovascular disease, heart failure, or renal failure could benefit from such a monotherapy. That will, however, require compelling results from targeted clinical trials. There are ongoing studies in patients with heart and renal failure, respectively (NCT03057951; NCT03078101; NCT03057977; NCT03594110; NCT03036124 [63]). Those studies include patients both with and without diabetes as well as obesity.

\subsection{Combination Therapy}

In contrast to monotherapy, an SGLT2 inhibitor in combination with a drug that reduces food intake is appealing as a means to mitigate the physiologic mechanisms that counteract weight loss (Fig. 1) [72]. Such combination pharmacotherapy may achieve greater reduction of body weight in two ways. First, the increased food intake evoked by energy loss during SGLT2 inhibition could partly be prevented by an appetite-reducing therapy. Second, the reduced cellular energy expenditure occurring after weight loss achieved by an appetite-reducing drug may be balanced by the urinary caloric loss secondary to glucosuria [41]. Therefore, the complementary mechanisms of action of an SGLT2 inhibitor and a GLP1-RA (through its effect to reduce appetite and possibly also its ability to slow gastric emptying) may provide an attractive approach for obesity treatment (Fig. 1). Our recent study addressing this treatment concept showed modest weight-loss effects [30, 31 ], but further studies with optimized doses are encouraged. Also, the trajectories of bodyweight change during SGLT2 inhibitor treatment varies substantially between individuals. Precision medicine approaches may also provide an opportunity to select patients who are receptive to the greater efficacy of this combination therapy. In our 
Fig. 1 Effects of SGLT2 inhibition in combination with a drug that reduces food intake (e.g., GLP1-RA) on energy intake and energy expenditure and compensatory effects

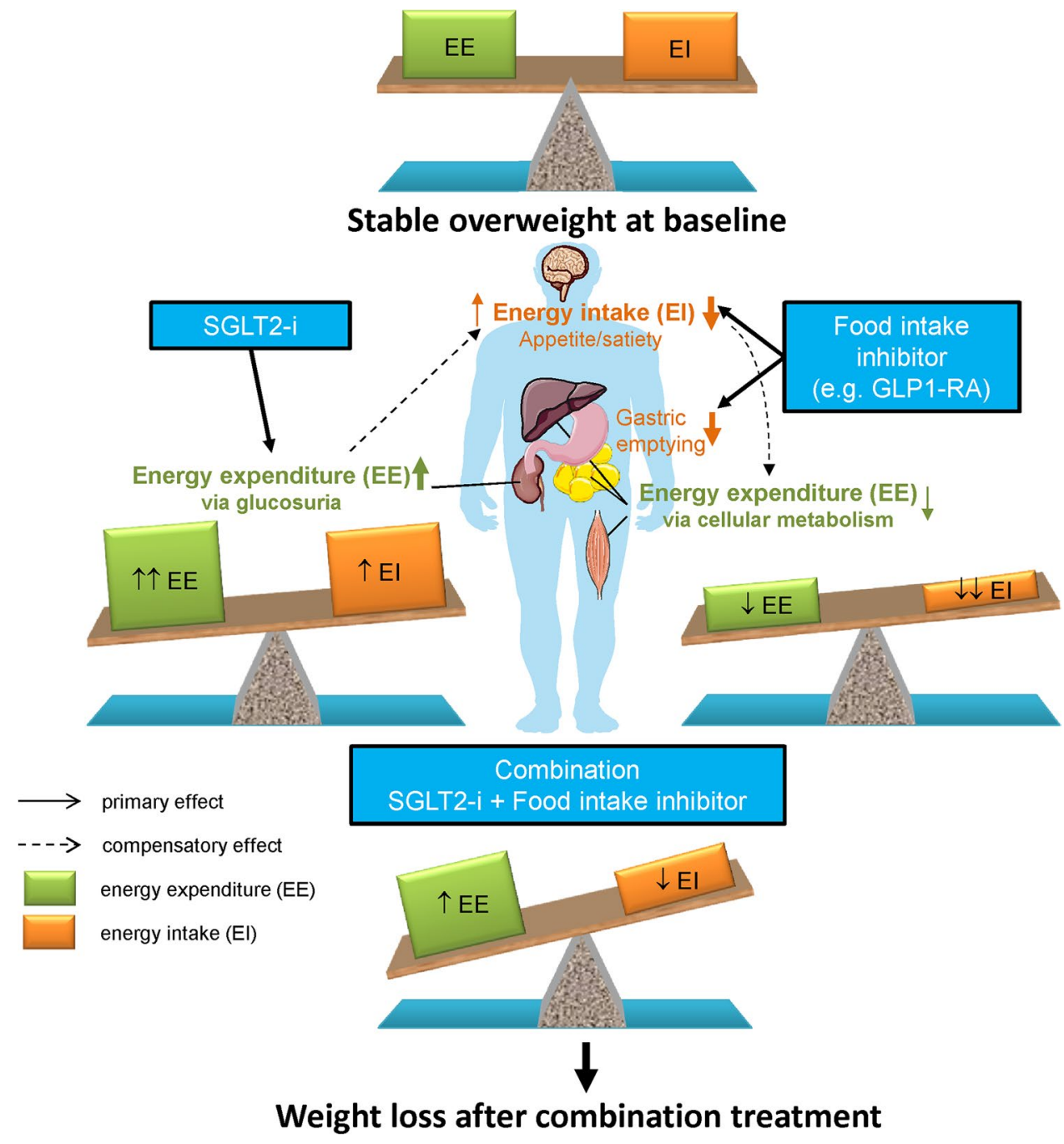

previous work on combination treatment with an SGLT2 inhibitor and GLP1-RA, we found some baseline characteristics that might identify responders, and relatively low BMI and low insulin secretion were associated with greater bodyweight loss [73]. In addition, the occurrence of the A allele of the SNP10010131, which is related to GLP-1-induced insulin secretion [74], was found to be associated with relatively greater bodyweight loss [73]. One study has found an association between a genetic variation in the SGLT2 gene (the rs9934336 G-allele) and increased plasma glucose and insulin concentrations during an oral glucose tolerance test [75]. However, no common genetic variants in the SGLT2 gene, or other genes, have shown a clinically relevant impact on treatment responses to SGLT2 inhibitors [76]. Further studies to characterize the good and poor responders are encouraged in the future.

Among patients with T2D [40], estimated caloric intake is increased by an average of 10-15\% during chronic treatment with an SGLT2 inhibitor; this offsets about $9 \mathrm{~kg}$ of an expected glucosuria-induced bodyweight loss of $11 \mathrm{~kg}$ over 2 years [77]. From the magnitude of bodyweight loss observed in the current study, it might be inferred that food intake was reduced by the addition of exenatide, thus counteracting the dapagliflozin-induced increase in food intake.

Further support for the combination of an SGLT2 inhibitor with agents that reduce appetite (and/or increase satiety) is provided by a clinical trial of canagliflozin and phentermine, given either in combination or each drug alone. In this study, there was about a $7 \%$ placebo-adjusted reduction in bodyweight with the combination and about $2 \%$ and $4 \%$ with canagliflozin or phentermine alone, respectively [42].

It would be of interest to further explore combination therapies involving an SGLT2 inhibitor together with an agent that reduces food intake. Such agents include novel more efficacious GLP1-RAs such as semaglutide (which is also being developed in an oral formulation) or so-called dual peptides like GLP1 + GIP [78] or GLP1 + glucagon [79]. The most recently approved antiobesity medicines, lorcaserin, topiramate + phentermine, 
and bupropion + naltrexone, respectively, work mainly via appetite reduction [80]. They could also very well become more effective if administered in combination with an SGLT2 inhibitor.

SGLT2 inhibitors increase glucagon secretion according to some reports, and this might reduce the glucoselowering effect [34]. However, co-administration with GLP1-RA may counteract this effect [73]. The prevention of the glucagon rise might improve the beneficial effects of the combination therapy to enhance glucose control and may support this combination therapy in clinical practice [81].

As far as we are aware, ongoing clinical trials are mainly looking at the effects of SGLT2 inhibitors in obese subjects without diabetes as a monotherapy (NCT03710460; NCT01756404; NCT02833415), and one study is evaluating the combination of dapagliflozin and exenatide in overweight/obese non-diabetic women with PCOS (NCT02635386). In particular, the combination of an SGLT2 inhibitor with one of the novel appetitereducing agents showing marked bodyweight loss (up to about $10 \mathrm{~kg}$ ), e.g., the LY3298176 GLP1 + GIP-RA [78] or injected semaglutide, would be attractive. The addition of SGLT2 inhibitors could probably improve both short-term weight loss and long-term weight maintenance.

\section{Conclusion}

Several studies support the concept that SGLT2 inhibitors can be effective as adjuvant weight loss therapy when given together with agents that reduce food intake, and such combination treatments appear attractive. In contrast, SGLT2 inhibitor monotherapy is not likely to provide sufficient weight loss for treatment of obesity per se, but could have other benefits in obese patients with comorbidities such as atherosclerotic cardiovascular disease, heart failure, or renal disease. Moreover, further research is warranted to address phenotypic and genotypic characteristics that may help to identify treatment responders to weight-loss therapies that include SGLT2 inhibitors.

Acknowledgements We thank our collaborators in related studies: at Uppsala University, in particular, Per Lundkvist; at AstraZeneca $\mathrm{AB}$, in particular, David Sjöström and Eva Johnsson; and at inScience Communications, Springer Healthcare, in particular, Julian G. Martins.

\section{Compliance with Ethical Standards}

Funding No funding was received for the preparation of this manuscript. Funding for our studies in this therapeutic area has been received from The Swedish Diabetes Foundation, EXODIAB, Ernfors Foundation, ALF grants, and AstraZeneca AB.
Conflict of interest JWE has received research grants or honoraria from AstraZeneca, Bristol-Myers-Squibb, Merck Sharpe and Dohme, Bayer, Sanofi, and NovoNordisk. MJP has no conflicts of interest to declare.

Open Access This article is distributed under the terms of the Creative Commons Attribution-NonCommercial 4.0 International License (http://creativecommons.org/licenses/by-nc/4.0/), which permits any noncommercial use, distribution, and reproduction in any medium, provided you give appropriate credit to the original author(s) and the source, provide a link to the Creative Commons license, and indicate if changes were made.

\section{References}

1. World Health Organization. Obesity and overweight fact sheet. 2017. http://www.who.int/mediacentre/factsheets/fs311/en/. Accessed 05 February 2018.

2. Martin-Rodriguez E, Guillen-Grima F, Marti A, BrugosLarumbe A. Comorbidity associated with obesity in a large population: the APNA study. Obesity research \& clinical practice. 2015;9(5):435-47.

3. Sirtori A, Brunani A, Capodaglio P, Berselli ME, Villa V, Ceriani F, et al. Patients with obesity-related comorbidities have higher disability compared with those without obesity-related comorbidities: results from a cross-sectional study. Int J Rehabil Res. 2016;39(1):63-9.

4. Simon GE, Von Korff M, Saunders K, Miglioretti DL, Crane PK, van Belle G, et al. Association between obesity and psychiatric disorders in the US adult population. Arch Gen Psychiatry. 2006;63(7):824-30.

5. Malnick SD, Knobler H. The medical complications of obesity. QJM. 2006;99(9):565-79.

6. Knowler WC, Barrett-Connor E, Fowler SE, Hamman RF, Lachin $\mathrm{JM}$, Walker EA, et al. Reduction in the incidence of type 2 diabetes with lifestyle intervention or metformin. N Engl J Med. 2002;346(6):393-403.

7. Lean ME, Leslie WS, Barnes AC, Brosnahan N, Thom G, McCombie L, et al. Primary care-led weight management for remission of type 2 diabetes (DiRECT): an open-label, clusterrandomised trial. Lancet. 2018;391(10120):541-51.

8. Lindstrom J, Louheranta A, Mannelin M, Rastas M, Salminen V, Eriksson J, et al. The Finnish Diabetes Prevention Study (DPS): lifestyle intervention and 3-year results on diet and physical activity. Diabetes Care. 2003;26(12):3230-6.

9. Sjostrom L, Peltonen M, Jacobson P, Sjostrom CD, Karason K, Wedel H, et al. Bariatric surgery and long-term cardiovascular events. JAMA. 2012;307(1):56-65.

10. Sjostrom L, Gummesson A, Sjostrom CD, Narbro K, Peltonen $\mathrm{M}$, Wedel $\mathrm{H}$, et al. Effects of bariatric surgery on cancer incidence in obese patients in Sweden (Swedish Obese Subjects Study): a prospective, controlled intervention trial. Lancet Oncol. 2009;10(7):653-62.

11. Sjostrom L, Narbro K, Sjostrom CD, Karason K, Larsson B, Wedel H, et al. Effects of bariatric surgery on mortality in Swedish obese subjects. N Engl J Med. 2007;357(8):741-52.

12. Wilding JP. Combination therapy for obesity. J Psychopharmacol. 2017;31(11):1503-8.

13. DeFronzo RA, Hompesch M, Kasichayanula S, Liu X, Hong Y, Pfister M, et al. Characterization of renal glucose reabsorption in response to dapagliflozin in healthy subjects and subjects with type 2 diabetes. Diabetes Care. 2013;36(10):3169-76. 
14. Henry RR, Klein EJ, Han J, Iqbal N. Efficacy and Tolerability of Exenatide Once Weekly Over 6 Years in Patients with Type 2 Diabetes: an Uncontrolled Open-Label Extension of the DURATION-1 Study. Diabetes Technol Ther. 2016;18(11):677-86.

15. Bolinder J, Ljunggren O, Johansson L, Wilding J, Langkilde AM, Sjostrom CD, et al. Dapagliflozin maintains glycaemic control while reducing weight and body fat mass over 2 years in patients with type 2 diabetes mellitus inadequately controlled on metformin. Diabetes Obes Metab. 2014;16(2):159-69.

16. Del Prato S, Nauck M, Duran-Garcia S, Maffei L, Rohwedder K, Theuerkauf A, et al. Long-term glycaemic response and tolerability of dapagliflozin versus a sulphonylurea as add-on therapy to metformin in patients with type 2 diabetes: 4-year data. Diabetes Obes Metab. 2015;17(6):581-90.

17. Frias JP, Guja C, Hardy E, Ahmed A, Dong F, Ohman P, et al. Exenatide once weekly plus dapagliflozin once daily versus exenatide or dapagliflozin alone in patients with type 2 diabetes inadequately controlled with metformin monotherapy (DURATION-8): a 28 week, multicentre, double-blind, phase 3, randomised controlled trial. The lancet Diabetes \& endocrinology. 2016;4(12):1004-16.

18. Zaccardi F, Htike ZZ, Webb DR, Khunti K, Davies MJ. Benefits and Harms of Once-Weekly Glucagon-like Peptide-1 Receptor Agonist Treatments: a Systematic Review and Network Metaanalysis. Ann Intern Med. 2016;164(2):102-13.

19. Potts JE, Gray LJ, Brady EM, Khunti K, Davies MJ, Bodicoat DH. The Effect of Glucagon-Like Peptide 1 Receptor Agonists on Weight Loss in Type 2 Diabetes: a Systematic Review and Mixed Treatment Comparison Meta-Analysis. PLoS ONE. 2015;10(6): 0126769.

20. Shyangdan DS, Uthman OA, Waugh N. SGLT-2 receptor inhibitors for treating patients with type 2 diabetes mellitus: a systematic review and network meta-analysis. BMJ Open. 2016;6(2):e009417.

21. Lundkvist P, Pereira MJ, Katsogiannos P, Sjostrom CD, Johnsson E, Eriksson JW. Dapagliflozin once daily plus exenatide once weekly in obese adults without diabetes: sustained reductions in bodyweight, glycaemia, and blood pressure over 1 year. Diabetes Obes Metab. 2017.

22. Mearns ES, Saulsberry WJ, White CM, Kohn CG, Lemieux S, Sihabout A, et al. Efficacy and safety of antihyperglycaemic drug regimens added to metformin and sulphonylurea therapy in Type 2 diabetes: a network meta-analysis. Diabet Med. 2015;32(12):1530-40.

23. Ramirez-Rodriguez AM, Gonzalez-Ortiz M, Martinez-Abundis E. Effect of Dapagliflozin on Insulin Secretion and Insulin Sensitivity in Patients with Prediabetes. Exp Clin Endocrinol Diabetes. 2018.

24. Busch RS, Kane MP. Combination SGLT2 inhibitor and GLP-1 receptor agonist therapy: a complementary approach to the treatment of type 2 diabetes. Postgrad Med. 2017;129(7):686-97.

25. Vasilakou D, Karagiannis T, Athanasiadou E, Mainou M, Liakos A, Bekiari E, et al. Sodium-glucose cotransporter 2 inhibitors for type 2 diabetes: a systematic review and meta-analysis. Ann Intern Med. 2013;159(4):262-74.

26. Zaccardi F, Webb DR, Htike ZZ, Youssef D, Khunti K, Davies MJ. Efficacy and safety of sodium-glucose co-transporter-2 inhibitors in type 2 diabetes mellitus: systematic review and network meta-analysis. Diabetes Obes Metab. 2016;18(8):783-94.

27. Liu XY, Zhang N, Chen R, Zhao JG, Yu P. Efficacy and safety of sodium-glucose cotransporter 2 inhibitors in type 2 diabetes: a meta-analysis of randomized controlled trials for 1 to 2 years. J Diabetes Complications. 2015;29(8):1295-303.

28. Maruthur NM, Tseng E, Hutfless S, Wilson LM, Suarez-Cuervo C, Berger Z, et al. Diabetes Medications as Monotherapy or Metformin-Based Combination Therapy for Type 2 Diabetes: a Systematic Review and Meta-analysis. Ann Intern Med. 2016;164(11):740-51.

29. Bays HE, Weinstein R, Law G, Canovatchel W. Canagliflozin: effects in overweight and obese subjects without diabetes mellitus. Obesity (Silver Spring). 2014;22(4):1042-9.

30. Lundkvist P, Sjostrom CD, Amini S, Pereira MJ, Johnsson E, Eriksson JW. Dapagliflozin once-daily and exenatide onceweekly dual therapy: a 24-week randomized, placebo-controlled, phase II study examining effects on body weight and prediabetes in obese adults without diabetes. Diabetes Obes Metab. 2017;19(1):49-60.

31. Lundkvist P, Pereira MJ, Katsogiannos P, Sjostrom CD, Johnsson E, Eriksson JW. Dapagliflozin once daily plus exenatide once weekly in obese adults without diabetes: sustained reductions in body weight, glycaemia and blood pressure over 1 year. Diabetes Obes Metab. 2017;19(9):1276-88.

32. Monami M, Nardini C, Mannucci E. Efficacy and safety of sodium glucose co-transport- 2 inhibitors in type 2 diabetes: a meta-analysis of randomized clinical trials. Diabetes Obes Metab. 2014;16(5):457-66.

33. Gerich JE. Physiology of glucose homeostasis. Diabetes Obes Metab. 2000;2(6):345-50.

34. Merovci A, Solis-Herrera C, Daniele G, Eldor R, Fiorentino TV, Tripathy D, et al. Dapagliflozin improves muscle insulin sensitivity but enhances endogenous glucose production. J Clin Invest. 2014;124(2):509-14.

35. Mearns ES, Sobieraj DM, White CM, Saulsberry WJ, Kohn CG, Doleh Y, et al. Comparative efficacy and safety of antidiabetic drug regimens added to metformin monotherapy in patients with type 2 diabetes: a network meta-analysis. PLoS ONE. 2015;10(4):e0125879.

36. Cai X, Yang W, Gao X, Chen Y, Zhou L, Zhang S, et al. The Association Between the Dosage of SGLT2 Inhibitor and Weight Reduction in Type 2 Diabetes Patients: a Meta-Analysis. Obesity. 2018;26(1):70-80.

37. Bolinder J, Ljunggren O, Johansson L, Wilding J, Langkilde AM, Sjostrom CD, et al. Dapagliflozin maintains glycaemic control while reducing weight and body fat mass over 2 years in patients with type 2 diabetes mellitus inadequately controlled on metformin. Diabetes Obes Metab. 2014;16(2):159-69.

38. Bailey CJ, Morales Villegas EC, Woo V, Tang W, Ptaszynska A, List JF. Efficacy and safety of dapagliflozin monotherapy in people with Type 2 diabetes: a randomized double-blind placebocontrolled 102-week trial. Diabet Med. 2015;32(4):531-41.

39. Del Prato S, Nauck M, Duran-Garcia S, Maffei L, Rohwedder K, Theuerkauf A, et al. Long-term glycaemic response and tolerability of dapagliflozin versus a sulphonylurea as add-on therapy to metformin in patients with type 2 diabetes: 4-year data. Diabetes Obes Metab. 2015;17(6):581-90.

40. Ferrannini G, Hach T, Crowe S, Sanghvi A, Hall KD, Ferrannini E. Energy Balance After Sodium-Glucose Cotransporter 2 Inhibition. Diabetes Care. 2015;38(9):1730-5.

41. Leibel RL, Rosenbaum M, Hirsch J. Changes in energy expenditure resulting from altered body weight. $\mathrm{N}$ Engl $\mathrm{J}$ Med. 1995;332(10):621-8.

42. Hollander P, Bays HE, Rosenstock J, Frustaci ME, Fung A, Vercruysse F, et al. Coadministration of Canagliflozin and Phentermine for Weight Management in Overweight and Obese Individuals Without Diabetes: a Randomized Clinical Trial. Diabetes Care. 2017;40(5):632-9.

43. Devenny JJ, Godonis HE, Harvey SJ, Rooney S, Cullen MJ, Pelleymounter MA. Weight loss induced by chronic dapagliflozin treatment is attenuated by compensatory hyperphagia in dietinduced obese (DIO) rats. Obesity. 2012;20(8):1645-52.

44. Yokono M, Takasu T, Hayashizaki Y, Mitsuoka K, Kihara R, Muramatsu Y, et al. SGLT2 selective inhibitor ipragliflozin 
reduces body fat mass by increasing fatty acid oxidation in highfat diet-induced obese rats. Eur J Pharmacol. 2014;727:66-74.

45. Ferrannini E, Baldi S, Frascerra S, Astiarraga B, Heise T, Bizzotto R, et al. Shift to Fatty Substrate Utilization in Response to Sodium-Glucose Cotransporter 2 Inhibition in Subjects Without Diabetes and Patients With Type 2 Diabetes. Diabetes. 2016;65(5):1190-5.

46. Xu L, Nagata N, Nagashimada M, Zhuge F, Ni Y, Chen G, et al. SGLT2 Inhibition by Empagliflozin Promotes Fat Utilization and Browning and Attenuates Inflammation and Insulin Resistance by Polarizing M2 Macrophages in Diet-induced Obese Mice. EBioMedicine. 2017;20:137-49.

47. Sugizaki T, Zhu S, Guo G, Matsumoto A, Zhao J, Endo M, et al. Treatment of diabetic mice with the SGLT2 inhibitor TA-1887 antagonizes diabetic cachexia and decreases mortality. NPJ Aging Mech Dis. 2017;3:12.

48. Greenberg AS, Obin MS. Obesity and the role of adipose tissue in inflammation and metabolism. Am J Clin Nutr. 2006;83(2):461S-5S.

49. Neal B, Perkovic V, Mahaffey KW, de Zeeuw D, Fulcher G, Erondu N, et al. Canagliflozin and Cardiovascular and Renal Events in Type 2 Diabetes. N Engl J Med. 2017;377(7):644-57.

50. Zinman B, Wanner C, Lachin JM, Fitchett D, Bluhmki E, Hantel $\mathrm{S}$, et al. Empagliflozin, Cardiovascular Outcomes, and Mortality in Type 2 Diabetes. N Engl J Med. 2015;373(22):2117-28.

51. Wiviott SD, Raz I, Bonaca MP, Mosenzon O, Kato ET, Cahn A et al. Dapagliflozin and cardiovascular outcomes in type 2 diabetes. N Engl J Med. 2019;380(4):347-57.

52. Rajasekeran H, Lytvyn Y, Cherney DZ. Sodium-glucose cotransporter 2 inhibition and cardiovascular risk reduction in patients with type 2 diabetes: the emerging role of natriuresis. Kidney Int. 2016;89(3):524-6.

53. Mudaliar S, Alloju S, Henry RR. Can a Shift in Fuel Energetics Explain the Beneficial Cardiorenal Outcomes in the EMPAREG OUTCOME Study? A Unifying Hypothesis. Diabetes Care. 2016;39(7):1115-22.

54. Zelniker TA, Wiviott SD, Raz I, Im K, Goodrich EL, Bonaca MP, et al. SGLT2 inhibitors for primary and secondary prevention of cardiovascular and renal outcomes in type 2 diabetes: a systematic review and meta-analysis of cardiovascular outcome trials. Lancet. 2019;393(10166):31-9.

55. Wilson PW, D’Agostino RB, Sullivan L, Parise H, Kannel WB. Overweight and obesity as determinants of cardiovascular risk: the Framingham experience. Arch Intern Med. 2002;162(16): 1867-72.

56. Oliva RV, Bakris GL. Blood pressure effects of sodium-glucose co-transport 2 (SGLT2) inhibitors. J Am Soc Hypertens. 2014;8(5):330-9.

57. Sjostrom CD, Hashemi M, Sugg J, Ptaszynska A, Johnsson E. Dapagliflozin-induced weight loss affects 24-week glycated haemoglobin and blood pressure levels. Diabetes Obes Metab. 2015;17(8):809-12.

58. Lambers Heerspink HJ, de Zeeuw D, Wie L, Leslie B, List J. Dapagliflozin a glucose-regulating drug with diuretic properties in subjects with type 2 diabetes. Diabetes Obes Metab. 2013;15(9):853-62.

59. Sano M. A new class of drugs for heart failure: sGLT2 inhibitors reduce sympathetic overactivity. J Cardiol. 2018;71(5):471-6.

60. Hall JE, do Carmo JM, da Silva AA, Wang Z, Hall ME. Obesityinduced hypertension: interaction of neurohumoral and renal mechanisms. Circ Res. 2015;116(6):991-1006.

61. Seidu S, Kunutsor SK, Cos X, Gillani S, Khunti K, For et al. SGLT2 inhibitors and renal outcomes in type 2 diabetes with or without renal impairment: A systematic review and metaanalysis. Prim Care Diabetes. 2018;12(3):265-83.
62. Wanner C. EMPA-REG OUTCOME: the Nephrologist's Point of View. Am J Cardiol. 2017;120(1S):S59-67.

63. Fioretto P, Del Prato S, Buse JB, Goldenberg R, Giorgino F, Reyner D, et al. Efficacy and safety of dapagliflozin in patients with type 2 diabetes and moderate renal impairment (chronic kidney disease stage 3A): the DERIVE Study. Diabetes Obes Metab. 2018;20(11):2532-40.

64. Henry RR, Thakkar P, Tong C, Polidori D, Alba M. Efficacy and Safety of Canagliflozin, a Sodium-Glucose Cotransporter 2 Inhibitor, as Add-on to Insulin in Patients With Type 1 Diabetes. Diabetes Care. 2015;38(12):2258-65.

65. Dandona P, Mathieu C, Phillip M, Hansen L, Griffen SC, Tschope D, et al. Efficacy and safety of dapagliflozin in patients with inadequately controlled type 1 diabetes (DEPICT-1): 24 week results from a multicentre, double-blind, phase 3, randomised controlled trial. The lancet Diabetes \& endocrinology. 2017;5(11):864-76.

66. Garg SK, Henry RR, Banks P, Buse JB, Davies MJ, Fulcher GR, et al. Effects of Sotagliflozin Added to Insulin in Patients with Type 1 Diabetes. N Engl J Med. 2017;377(24):2337-48.

67. Alsahli M, Gerich JE. Hypoglycemia in Patients with Diabetes and Renal Disease. J Clin Med. 2015;4(5):948-64.

68. Ferrannini E, Muscelli E, Frascerra S, Baldi S, Mari A, Heise $\mathrm{T}$, et al. Metabolic response to sodium-glucose cotransporter 2 inhibition in type 2 diabetic patients. J Clin Invest. 2014;124(2):499-508.

69. Peters AL, Buschur EO, Buse JB, Cohan P, Diner JC, Hirsch IB. Euglycemic Diabetic Ketoacidosis: a Potential Complication of Treatment With Sodium-Glucose Cotransporter 2 Inhibition. Diabetes Care. 2015;38(9):1687-93.

70. Handelsman Y, Henry RR, Bloomgarden ZT, Dagogo-Jack S, DeFronzo RA, Einhorn D, et al. American Association of Clinical Endocrinologists and American College of Endocrinology Position Statement on the Association of Sglt-2 Inhibitors and Diabetic Ketoacidosis. Endocr Pract. 2016;22(6):753-62.

71. Ryan P, J.B. B, Schuemie M, DeFalco F, Yuan Z, Stang P et al. Canagliflozin versus other antihyperglycaemic agents on the risk of below-knee amputation for patients with type 2 diabetes: a real world analysis of $>700,000$ US patients. EASD 54th Annual Meeting 2018; http://abstractsonline.com/pp8/\#!/4612/presentati on/41802018.

72. Ravussin Y, Leibel RL, Ferrante AW Jr. A missing link in body weight homeostasis: the catabolic signal of the overfed state. Cell Metab. 2014;20(4):565-72.

73. Pereira MJ, Lundkvist P, Kamble PG, Lau J, Martins JG, Sjostrom CD, et al. A Randomized Controlled Trial of Dapagliflozin Plus Once-Weekly Exenatide Versus Placebo in Individuals with Obesity and Without Diabetes: metabolic Effects and Markers Associated with Bodyweight Loss. Diabetes Ther. 2018;9(4):1511-32.

74. Schafer SA, Mussig K, Staiger H, Machicao F, Stefan N, Gallwitz $\mathrm{B}$, et al. A common genetic variant in WFS1 determines impaired glucagon-like peptide-1-induced insulin secretion. Diabetologia. 2009;52(6):1075-82.

75. Enigk U, Breitfeld J, Schleinitz D, Dietrich K, Halbritter J, Fischer-Rosinsky A, et al. Role of genetic variation in the human sodium-glucose cotransporter 2 gene (SGLT2) in glucose homeostasis. Pharmacogenomics. 2011;12(8):1119-26.

76. Zimdahl H, Haupt A, Brendel M, Bour L, Machicao F, Salsali A, et al. Influence of common polymorphisms in the SLC5A2 gene on metabolic traits in subjects at increased risk of diabetes and on response to empagliflozin treatment in patients with diabetes. Pharmacogenet Genomics. 2017;27(4):135-42.

77. Hall KD, Sacks G, Chandramohan D, Chow CC, Wang YC, Gortmaker SL, et al. Quantification of the effect of energy imbalance on bodyweight. Lancet. 2011;378(9793):826-37. 
78. Frias JP, Nauck MA, Van J, Kutner ME, Cui X, Benson C et al. Efficacy and safety of LY3298176, a novel dual GIP and GLP-1 receptor agonist, in patients with type 2 diabetes: a randomised, placebo-controlled and active comparator-controlled phase 2 trial. Lancet. 2018.

79. Ambery P, Parker VE, Stumvoll M, Posch MG, Heise T, PlumMoerschel L, et al. MEDI0382, a GLP-1 and glucagon receptor dual agonist, in obese or overweight patients with type 2 diabetes: a randomised, controlled, double-blind, ascending dose and phase 2a study. Lancet. 2018;391(10140):2607-18.

80. Citrome L. Lorcaserin, phentermine topiramate combination, and naltrexone bupropion combination for weight loss: the 15-min challenge to sort these agents out. Int J Clin Pract. 2014;68(12):1401-5.

81. Deol H, Lekkakou L, Viswanath AK, Pappachan JM. Combination therapy with GLP-1 analogues and SGLT-2 inhibitors in the management of diabesity: the real world experience. Endocrine. 2017;55(1):173-8.

82. Napolitano A, Miller S, Murgatroyd PR, Hussey E, Dobbins RL, Bullmore ET et al. Exploring glycosuria as a mechanism for weight and fat mass reduction. A pilot study with remogliflozin etabonate and sergliflozin etabonate in healthy obese subjects. $\mathbf{J}$ Clin Transl Endocrinol. 2014;1(1):e3-e8.

83. Lundkvist P, Sjostrom CD, Amini S, Pereira MJ, Johnsson E, Eriksson JW. Dapagliflozin once-daily and exenatide onceweekly dual therapy: A 24-week randomized, placebo-controlled, phase II study examining effects on body weight and prediabetes in obese adults without diabetes. Diabetes Obes Metab. 2016.

84. Bailey CJ, Iqbal N, T'Joen C, List JF. Dapagliflozin monotherapy in drug-naive patients with diabetes: a randomizedcontrolled trial of low-dose range. Diabetes Obes Metab. 2012;14(10):951-9.

85. Ferrannini E, Ramos SJ, Salsali A, Tang W, List JF. Dapagliflozin monotherapy in type 2 diabetic patients with inadequate glycemic control by diet and exercise: a randomized, double-blind, placebo-controlled, phase 3 trial. Diabetes Care. 2010;33(10):2217-24.

86. Ji L, Ma J, Li H, Mansfield TA, T'Joen C L, Iqbal N et al. Dapagliflozin as monotherapy in drug-naive Asian patients with type 2 diabetes mellitus: a randomized, blinded, prospective phase III study. Clin Ther. 2014;36(1):84-100 e9.

87. Kaku K, Kiyosue A, Inoue S, Ueda N, Tokudome T, Yang J, et al. Efficacy and safety of dapagliflozin monotherapy in Japanese patients with type 2 diabetes inadequately controlled by diet and exercise. Diabetes Obes Metab. 2014;16(11):1102-10.

88. Bailey CJ, Gross JL, Pieters A, Bastien A, List JF. Effect of dapagliflozin in patients with type 2 diabetes who have inadequate glycaemic control with metformin: a randomised, double-blind, placebo-controlled trial. Lancet. 2010;375(9733):2223-33.

89. Bailey CJ, Gross JL, Hennicken D, Iqbal N, Mansfield TA, List JF. Dapagliflozin add-on to metformin in type 2 diabetes inadequately controlled with metformin: a randomized, double-blind, placebo-controlled 102-week trial. BMC Med. 2013;11:43.

90. Bolinder J, Ljunggren O, Kullberg J, Johansson L, Wilding J, Langkilde AM, et al. Effects of dapagliflozin on body weight, total fat mass, and regional adipose tissue distribution in patients with type 2 diabetes mellitus with inadequate glycemic control on metformin. J Clin Endocrinol Metab. 2012;97(3):1020-31.

91. Strojek K, Yoon KH, Hruba V, Elze M, Langkilde AM, Parikh S. Effect of dapagliflozin in patients with type 2 diabetes who have inadequate glycaemic control with glimepiride: a randomized, 24-week, double-blind, placebo-controlled trial. Diabetes Obes Metab. 2011;13(10):928-38.

92. Strojek K, Yoon KH, Hruba V, Sugg J, Langkilde AM, Parikh S. Dapagliflozin added to glimepiride in patients with type 2 diabetes mellitus sustains glycemic control and weight loss over
48 weeks: a randomized, double-blind, parallel-group, placebocontrolled trial. Diabetes Ther. 2014;5(1):267-83.

93. Nauck MA, Del Prato S, Meier JJ, Duran-Garcia S, Rohwedder K, Elze M, et al. Dapagliflozin versus glipizide as add-on therapy in patients with type 2 diabetes who have inadequate glycemic control with metformin: a randomized, 52-week, double-blind, active-controlled noninferiority trial. Diabetes Care. 2011;34(9):2015-22.

94. Nauck MA, Del Prato S, Duran-Garcia S, Rohwedder K, Langkilde AM, Sugg J, et al. Durability of glycaemic efficacy over 2 years with dapagliflozin versus glipizide as add-on therapies in patients whose type 2 diabetes mellitus is inadequately controlled with metformin. Diabetes Obes Metab. 2014;16(11):1111-20.

95. Fulcher G, Matthews DR, Perkovic V, de Zeeuw D, Mahaffey $\mathrm{KW}$, Mathieu C, et al. Efficacy and safety of canagliflozin when used in conjunction with incretin-mimetic therapy in patients with type 2 diabetes. Diabetes Obes Metab. 2016;18(1):82-91.

96. Ludvik B, Frias JP, Tinahones FJ, Wainstein J, Jiang H, Robertson KE, et al. Dulaglutide as add-on therapy to SGLT2 inhibitors in patients with inadequately controlled type 2 diabetes (AWARD-10): a 24-week, randomised, double-blind, placebo-controlled trial. The lancet Diabetes \& endocrinology. 2018;6(5):370-81.

97. Jabbour SA, Hardy E, Sugg J, Parikh S, Study G. Dapagliflozin is effective as add-on therapy to sitagliptin with or without metformin: a 24-week, multicenter, randomized, double-blind, placebo-controlled study. Diabetes Care. 2014;37(3):740-50.

98. DeFronzo RA, Lewin A, Patel S, Liu D, Kaste R, Woerle HJ, et al. Combination of empagliflozin and linagliptin as second-line therapy in subjects with type 2 diabetes inadequately controlled on metformin. Diabetes Care. 2015;38(3):384-93.

99. Pratley RE, Eldor R, Raji A, Golm G, Huyck SB, Qiu Y, et al. Ertugliflozin plus sitagliptin versus either individual agent over 52 weeks in patients with type 2 diabetes mellitus inadequately controlled with metformin: the VERTIS FACTORIAL randomized trial. Diabetes Obes Metab. 2018;20(5):1111-20.

100. Rosenstock J, Hansen L, Zee P, Li Y, Cook W, Hirshberg B, et al. Dual add-on therapy in type 2 diabetes poorly controlled with metformin monotherapy: a randomized double-blind trial of saxagliptin plus dapagliflozin addition versus single addition of saxagliptin or dapagliflozin to metformin. Diabetes Care. 2015;38(3):376-83.

101. Mathieu C, Herrera Marmolejo M, Gonzalez Gonzalez JG, Hansen L, Chen H, Johnsson E, et al. Efficacy and safety of triple therapy with dapagliflozin add-on to saxagliptin plus metformin over 52 weeks in patients with type 2 diabetes. Diabetes Obes Metab. 2016;18(11):1134-7.

102. Rosenstock J, Vico M, Wei L, Salsali A, List JF. Effects of dapagliflozin, an SGLT2 inhibitor, on $\mathrm{HbA}(1 \mathrm{c})$, body weight, and hypoglycemia risk in patients with type 2 diabetes inadequately controlled on pioglitazone monotherapy. Diabetes Care. 2012;35(7):1473-8.

103. Kovacs CS, Seshiah V, Swallow R, Jones R, Rattunde H, Woerle $\mathrm{HJ}$, et al. Empagliflozin improves glycaemic and weight control as add-on therapy to pioglitazone or pioglitazone plus metformin in patients with type 2 diabetes: a 24-week, randomized, placebocontrolled trial. Diabetes Obes Metab. 2014;16(2):147-58.

104. Wilding JP, Woo V, Rohwedder K, Sugg J, Parikh S, Dapagliflozin 006 Study G. Dapagliflozin in patients with type 2 diabetes receiving high doses of insulin: efficacy and safety over 2 years. Diabetes Obes Metab. 2014;16(2):124-36.

105. Rosenstock J, Jelaska A, Frappin G, Salsali A, Kim G, Woerle HJ, et al. Improved glucose control with weight loss, lower insulin doses, and no increased hypoglycemia with empagliflozin added to titrated multiple daily injections of insulin in obese inadequately controlled type 2 diabetes. Diabetes Care. 2014;37(7):1815-23. 